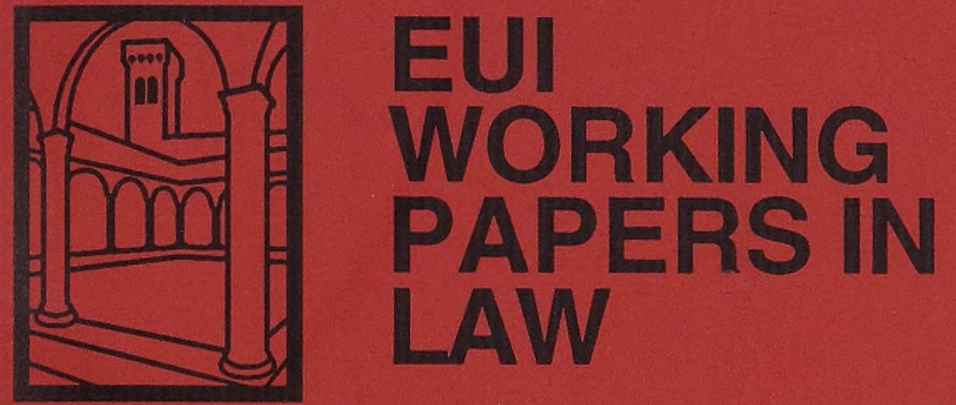

EUI Working Paper LA W No. 93/5

Soft Law and Institutional Practice in the European Community

FRANCIS SNYDER 
Please note

As from January 1990 the EUI Working Paper Series is divided into six sub-series, each sub-series is numbered individually (e.g. EUI Working Paper ECO No 90/1). 
EUROPEAN UNIVERSITY INSTITUTE, FLORENCE

DEPARTMENT OF LAW

\section{EUI Working Paper LAW No. 93/5 \\ Soft Law and Institutional Practice in the European Community}

FRANCIS SNYDER 
All rights reserved.

No part of this paper may be reproduced in any form without permission of the author.

(C) Francis Snyder

Printed in Italy in June 1993

European University Institute

Badia Fiesolana

I - 50016 San Domenico (FI)

Italy 


\title{
Soft Law and Institutional Practice in the European Community
}

\author{
FRANCIS SNYDER*
}

\section{Introduction}

Law in context is widely recognised as a distinctive approach to legal studies. Only recently, however, has it been applied to European Cornmunity law. 1 This article aims to contribute to the development of the contextual approach.

In order to situate the article in relation to other studies of European Community law, let us draw a heuristic distinction between different ways of looking at law, legal institutions and legal processes. The perspective of the lawyer in practice, either private or public, is concerned primarily with finding solutions to specific legal issues, which arise in particular cases and are brought to the lawyer by clients. The perspective of the policy-maker considers law mainly as an instrument, and asks whether and how it contributes to or hinders the achievement of policy objectives. The doctrinal perspective on law aims mainly to analyse, systematise and give a exposition of legal norms, demonstrating their coherence and, if necessary, criticising their

* Professor of European Community Law, European University Institute, Florence; Professor of Law, College of Europe, Bruges; Honorary Visiting Professor of Law, University College London. The author thanks Jason Coppel, Renaud Dehousse, Christian Joerges, Giandomenico Majone and Stephen Weatherill for their contributions to this article. He alone of course is responsible for its contents.

1 See Francis Snyder, New Directions in European Community Law (London: Weidenfeld and Nicolson, 1990); Francis Snyder European Community Law, 2 volumes (Aldershot: Dartmouth Publishing Company, 1993). 
contradictions. The perspective of law in context may be summarised for our purposes as follows: either law is viewed from the standpoint of other disciplines, using their theories and modes of analysis; or law provides the starting point but is situated in a broader context, whether social, economic, political or cultural: both strands aim ultimately to contribute to a social theory of law.

This article gives an example of a contextual approach; it also touches on questions of legal policy. It considers some aspects of Commission soft law and institutional practice in the European Community. By 'soft law', I mean 'rules of conduct which, in principle, have no legally binding force but which nevertheless may have practical effects'. ${ }^{2}$ The principal purposes of the discussion are two-fold. First, on the basis of the example of soft law, the article seeks to illuminate inter-institutional relations in the European Community, in particular the relations between the Commission and the European Court of Justice. Second, it examines some of the implications of the increasing use of soft law for the institutional structure of the European Community as a whole.

2 Snyder, 'The Effectiveness of European Community Law: Institutions, Processes, Tools and Techniques', Modern Law Review 56, 1993, pp 19-54 at 32. 


\section{Towards 'Regulation By Publication'?3}

Soft law has long been employed in the Community system. ${ }^{3}$ The most celebrated example is perhaps the Commission's Communication ${ }^{4}$ on the consequences of the judgment of the Court of Justice in Cassis de Dijon. ${ }^{5}$ Then a new type of quasi-legal act, it signaled the adoption by the Commission of a new strategy for completing the internal market. The judgment by the Court of Justice established the principle of 'mutual recognition'. The efforts of the Commission were henceforth devoted mainly to ensuring regulatory competition: the rigid harmonisation of national laws by means of EC legislation was replaced by a strategy of selective litigation by the Commission against Member States under Article 169 EEC. This strategy was consolidated, and the increasing use of soft law announced, by the Commission's White Paper in 1985.6

During the last decade, Community institutions have resorted to soft law with increasing frequency. This trend represents in part a predictable feature of administrative development, 7 in part a comprehensible response to institu-

3 See Melchior, 'Les communications de la Commission: Contribution à l'étude des actes communautaires non prévus par les traités', in Mélanges Fernand Dehousse vol. 2 La construction européenne (Paris: Nathan; Brussels: Labor, 1979), pp. 243-258; Mattera, Le marché unique européen: Ses règles, son fonctionnement (Paris, Jupiter, 2nd ed. 1990), pp 43-46; K.C. Wellens and G.M. Borchardt, 'Soft Law in European Community Law', 14, 1989, pp 267-321; Mariacristina Reale, 'Le comunicazioni interpretative della Commissione della Comunità Europea', Tesi di Laurea in Diritto delle Comunità Europea, Università degli Studi di Bologna, Sessione invernale, 1989-1990; Mariacristina Reale, 'Uno Strumento di "Soft Law" Comunitario', 18, Giugno 1992, pp 26-30.

4 Commission of the European Communities, 'Communication from the Commission concerning the Consequences of the Judgment given by the Court of Justice on 20 February 1877 in Case 120/78 ( ), OJ 1989 C256/2.

5 Case $120 / 78$ v [1979] ECR 649.

6 Commission of the European Communities, 'Completing the Internal Market' (White Paper from the Commission to the European Council, Milan, 28-29 June 1985), $\operatorname{COM}(85) 310$ final (1985).

7 See e.g. Jean Vergès, 'De quelques méthodes de développement institutionnel des Communautés européennes', in (Paris, Pedone, 1980), pp 501-517; Robert Baldwin and John Houghton, 'Circular Arguments: The Status and Legitimacy of Administrative Rules' 1986, pp 239-284; Administrative Review Council, Report to the Attorney General, Report No. 35 (Canberra: Australian Government Publishing Service, 1992); 
tional inertia, and in part a questionable attempt to circumvent or avoid the implications of failures to reach political agreement. ${ }^{8}$ From the standpoint of the Commission, for instance, soft law has several advantages. Let us take the example of Commission communications, since this form of soft law will be discussed in detail later. Communications, like legislation, may concern broad areas of policy, rather than treating matters in an ad hoc and piecemeal manner. They are under the control of the Commission, thus in effect bypassing the Council. They are proactive rather than reactive, so that the Commission, without waiting for the Council, the European Parliament or the Court of Justice, can present its interpretation and stake out its position with regard to entire economic sectors. 9

Already an important source of Community rules, Commission soft law is likely to have an even greater impact on the Community system in the future. This is so for two reasons. First, the Commission is being asked now to assume administrative responsibility for managing a broader range of matters, often in conjunction with the Member States. Yet its means of action remain relatively limited and are being increasingly constricted. In debates concerning the Maastricht Treaty, the Commission has frequently been criticised. Its right to initiate legislation, which has always been constrained, has now been eroded, formally as well as in practice. 10 The same could be said of its pow-

see also Isaac Ehrlich and Richard A. Posner, 'An Economic Analysis of Legal Rulemaking', 1974, 3, 1, pp 257-286.

8 Broadly similar issues have been raised with regard to the Court of Justice. See especially Pierre Pescatore, 'La carence du legislateur et le devoir du juge', in (Saarbrücken: Europa Institute, 1983; Hjalte Rasmussen, (Dordrecht: Martinus Nijhoff, 1986); Easson, 'Legal Approaches to European Integration: The Role of Court and Legislature in the Completion of the European Common Market', 12, 2-3, 1989, pp 101-119.

9 This paragraph draws on my contribution to the United Kingdom report in Schwarze, Govaere, Helin and Van de Bossche (eds.), (Baden-Baden: Nomos, 1991), p. 611.

10 See Dehousse, Joerges, Majone, Snyder in collaboration with Everson, 'Europe after 1992: New Regulatory Strategies', EUI Working Paper LAW No. $92 / 31$ (1992), pp 910. 
ers to implement Community legislation. ${ }^{11}$ As a result of these and other factors, 12 the Commission may be expected to favour soft law over hard law. Put colloquially, '1993 is not only the year of the Single Market, it is the year of the ... guideline[.]...'13

Second, an increase in the use of Commission soft law, and Community soft law generally, is likely to result from the debate concerning subsidiarity as provided in the Maastricht Treaty. This likelihood, however, raises issues of fundamental importance in the Community system, especially with regard to relations among Community institutions. The emerging dilemmas can be illustrated by focussing on what may be called 'the paradox of subsidiarity'.

\section{The Paradox of Subsidiarity}

The principle of subsidiarity was intended initially as a response to calls for greater openness and democracy in Community decision-making. ${ }^{14}$ As expressed in the Maastricht Treaty, and as now commonly understood, it is designed in principle to allocate more decision-making power to the Member States. 15 In practice, however, the implementation of this principle may have perverse unintended consequences, which though perhaps consistent with the letter of the principle are contrary to the spirit of the principle and its initial aims.

11 See especially Case 167/88 v [1989] ECR 1653; Case 22/88 v [1989] ECR 2049; Case $16 / 88$ v [1989] ECR 3457. See also Case C-8/88 v [1992] 1 CMLR 409; Case C-240/90 $v$ Judgment of 27 October 1992, not yet reported.

12 See Francis Snyder, 'The Effectiveness of European Community Law: Institutions, Processes, Tools and Techniques', 56, 1993, pp 19-54 at 31-32.

13 Waterhouse, 'When guidelines are the limit', (Birmingham), Monday, January 4, 1993, p 8.

14 See e.g. Marc Wilke and Helen Wallace, RIIA Discussion Papers 27 (London: The Royal Institute of International Affairs, 1990).

15 This in itself represents a substantial change from the original principle. 
In October 1992 the Commission made a communication to the Council and the European Parliament. In its view, subsidiarity involved not only the concept of subsidiarity stricto sensu, namely the question as to who should exercise legislative power. It also embraced the concept of proportionality, that is, the question as to whether and how the power should be exercised. This interpretation has been accepted by the European Council.16 The proposal by the Commission for an inter-institutional agreement with the Council and the European Parliament on this basis has also been accepted by the European Parliament and the Member States. 17

Furthermore, the principle of proportionality has been interpreted by both Community institutions and national governments to give priority to measures which are not legally binding, that is, to soft law. According to the Commission, ' $[t]$ he main choice where subsidiarity [in the sense of proportionality] is concerned is between binding and non-binding measures'. 18 '.[I]f action is needed to achieve the objectives of the Treaty, it must not be disproportionate; this implies that recourse to the most binding instruments should be used as a last resort'. 19 This view has been accepted by the European Parliament and the Member States. As expressed at the December 1992 European Council meeting in Edinburgh:

16 See Conclusions of the Presidency, European Council in Edinburgh, 11-12 December 1992, Annex I to Part A, 'Overall Approach to the Application by the Council of the Subsidiarity Principle and Article 3b of the Treaty on European Union'.

17 See Conclusions of the Presidency, European Council in Edinburgh, 11-12 December 1992, Annex I to Part A, 'Overall Approach to the Application by the Council of the Subsidiarity Principle and Article $3 b$ of the Treaty on European Union', p. 9. On the Commission proposal for an inter-institutional agreement, see Commission of the European Communities, 'The principle of subsidiarity: Communication of the Commission to the Council and the European Parliament', SEC(92)1990 final, Brussels, 27 October 1992.

18 Commission of the European Communities, 'The principle of subsidiarity: Communication of the Commission to the Council and the European Parliament', SEC(92)1990 final, Brussels, 27 October 1992, p. 14.

19 Commission of the European Communities, 'The principle of subsidiarity: Communication of the Commission to the Council and the European Parliament', SEC(92)1990 final, Brussels, 27 October 1992, p. 5, see also p. 4. 
The form of action should be as simple as possible, consistent with satisfactory achievement of the objective of the measure and the need for effective enforcement. The Community should legislate only to the extent necessary. Other things being equal, directives should be preferred to regulations and framework directives to detailed measures. Non-binding measures such as recommendations should be preferred where appropriate. Consideration should be given where appropriate to the use of voluntary codes of conduct. 20

The priority to be given to soft law thus appears to form one of the guidelines for the application of the subsidiarity principle and Article $3 b$ of the Maastricht Treaty. 21

The concept of subsidiarity was proposed initially as one answer to the European Community's legitimacy crisis. The conjunction of these interpretations gives priority, however, first to efficiency, and second perhaps to legality, but to both at the expense of legitimacy. Hence the paradox of subsidiarity. In its narrow formulation, the principle of subsidiarity, understood here in the sense of proportionality, is apparently intended to decrease the intensity of Community action. Yet it appears to lead in practice to the result that Community action, when taken, is increasingly discretionary and is subject only with difficulty to legal controls. In its broader formulation, referring to its initial purposes, the principle of subsidiarity is intended to increase the openness and democracy of Community decision-making and hence of the Community system. Yet the way in which the principle has been interpreted may lead to implementation by means of an inter-institutional agreement, a singularly untransparent Community instrument. It thus may simply worsen the problem of legitimacy.

20 Conclusions of the Presidency, European Council in Edinburgh, 11-12 December 1992 , Annex I to Part A, 'Overall Approach to the Application by the Council of the Subsidiarity Principle and Article $3 b$ of the Treaty on European Union', p. 9.

21 See also 'Subsidiarité: Nouveau code de conduite pour construire l'Europe', (Commission des Communautés Européennes, Bulletin mensuel du Bureau en Belgique), 172 , février 1993, pp 12-13. 


\section{Institutional Practice and the Meaning of Soft Law}

The meaning of Community soft law will be determined to a large extent by the practice of Community institutions. With regard to Commission soft law in particular, a fundamental part is being played by the European courts. The European Court of Justice and the Court of First Instance, each within its sphere of jurisdiction, are meant to ensure that in the Community system 'the law is observed'. 22 Not all forms of Commission soft law have been considered so far by courts. The cases to date concern communications; codes of conduct; codes, guidelines or frameworks; and internal instructions. 23 In deciding these cases, the European courts, while fulfilling the judicial function, have helped to define the balance in practice between legality, efficiency and legitimacy in the Community system.

The European courts are not however merely passive and reactive. As judicial institutions, viewed in isolation, they obtain their cases in a reactive manner. From the standpoint of the Commission, however, the decisions of the Court of Justice and the Court of First Instance constitute structures, in the sense that they are 'simultaneously representations of previous outcomes as well as frameworks, influences and sometimes determinants of continuing conflicts and compromises'.24 Judicial decisions thus not only elaborate the norms comprising Community law. They are among the determinants of Community policy and of the basic features of Community institutional law and politics.

22 Art. 164 EEC; see also Koenraad Lenaerts, 'The Development of the Judicial Process in the European Community after the Establishment of the Court of First Instance', Vol I, Book I (Dordrecht, Kluwer, 1991), pp 53-113 at 70, 86-89.

23 This terminology is that used by the Commission. It also presents the measures starting with those which apparently are farthest from the EEC Treaty. For a classification of soft law (in the United Kingdom) according to function, see Robert Baldwin and John Houghton, 'Circular Arguments: The Status and Legitimacy of Administrative Rules', 1986, pp 239-284. For a classification of Community soft law according to forum, form and content, see K.C. Wellens and G.M. Borchardt, 'Soft Law in European Community Law', 14, 1989, pp 267-321 at 300-301.

24 Francis Snyder, (London, Weidenfeld \& Nicolson, 1990), p. 61. 
In seeking to determine the meaning of Commission soft law in practice, we need to view the Commission and the Court in interaction: not necessarily as acting in tandem, for example to advance European integration; still less as partners in negotiating through litigation the shape of the Community of the future; but rather, and more modestly, as each having an effect on the other, such that the result of each institution's decisional processes are incorporated as an input into the decisional processes of the other. The interaction between the Commission and the European courts is not, however, merely a process of reciprocity. Instead it is recursive: it involves the reproduction of both institutions and norms, and the processes of reproduction occur in and by means of practices which are organised by these institutions and norms. 25 The Commission and the Court of Justice together thus constitute what Giddens has called a structural set, which is 'formed through the mutual convertability of rules and resources in one domain of action into those pertaining to another'. 26

The point of departure for analysing this process depends on one's objectives. For the present purposes, we will conceive of it as beginning with a Commission soft law. The soft law then is considered by a court, and the judicial decision subsequently influences the practice of the Commission, either with regard to the same subject matter or in more general terms of institutional practice. The following discussion focusses on a single case, which reveals with particular clarity the recursive relations between the Commission and the Court of Justice.

25 Anthony Giddens, (London: Hutchinson, 1975), esp. pp 118-126. They thus exemplify the duality of structure, that is, that social structures are both constituted by human agency, and yet at the same time are the very medium of this constitution'[ibid., p. 121; original emphasis omitted].

26 Anthony Giddens, 'A Reply to My Critics', in David Held and John B. Thompson, (Cambridge: Cambridge University Press, 1989) pp 253-259 at 299. 


\section{The Deufil Case}

Case 310/85 Deufil 27 concerned Commission guidelines in the form of a code on state aids to the textile industry. The case was brought under Article 173(2) EEC by a manufacturer of synthetic fibres. The plaintiff sought the annulment of a Commission decision, according to which the aid granted to the plaintiff under the German law relating to investment subsidies and the joint Federal Government/ regional aid programme was illegal and should be recovered.

The aid code was the latest in a series of Commission measures concerning the textile sector. On 30 July 1971 the Commission addressed to the Member States a memorandum entitled 'Containment at Community level of aid to the textile industry'. In 1977 it drew up new guidelines addressed to the Member States under the title 'Consideration of the present position in regard to aid to the textile and clothing industry'. Subsequently, by letter of 19 July 1977, it notified the Member States of an 'aid code' concerning synthetic fibres and yarns; the code was extended in 1979, 1981 and 1983.28 Finally, on 4 July 1985 the Commission notified the Member States that it considered that the system of supervision of aid introduced in 1977 should be extended to July 1987. In addition, not only should it continue to cover acrylic, polyester and polyamide; it should also be extended to polypropylene fibre and yarns.

The changing form of these measures reflected the Commission's growing concern about the textile market during a period of fifteen years. As the Commission's view of the market became more pessimistic, the document evolved from memorandum to guidelines and then to an aid code. The measures thus tended gradually towards formalism, obligation and legalism,

27 v [1987] ECR 901

28 See [1987] ECR 901 at 902-903 (Report for the Hearing), 913-914 (Opinion of Advocate-General Darmon). 
though without ever taking the form of a legally binding act. It was, however, always recognised by the Commission that, regardless of its formal title, the document was without prejudice to the provisions of the EEC Treaty. Nevertheless the measures increasingly gave precise policy directions to the Member States, described specific consequences for action inconsistent with its content, and, by necessary implication, spelled out with greater clarity the basic substantive principles of Commission state aids decisions in the textile sector. 29

In 1983 the German Federal Government and North Rhine-Westphalia granted aid to the applicant. The aid was not previously notified to the Commission. In February 1984 the Federal Government informed the Commission of the aid. The Commission concluded that the aid was an infringement of Article 93(3) EEC. On 10 July 1985 it adopted the contested decision.

The arguments of the parties focussed on the the interpretation of the aid code and its effects. The applicant claimed that it had received the aid on the basis of definitive decisions and precise instructions, and that it had used the aid to convert its production to a product not then subject to the 'code'. In its view, the aid was acceptable because the products of its factory were not covered by the code. It argued therefore that the Commission's order to Germany to recover the aid was contrary to the principle of legitimate expectations. In the view of the Commmission, ultimately accepted by the Court of Justice, 30 however, the applicant had used the aid for normal modernisation, not for restructuring. Not only had the applicant increased its production capacity for polyamide yarn, which had always been covered by the code. It also increased 
its capacity for polypropylene fibre, which though 'not subject at the material time to the aid code, was in oversupply in the Community[;] the Commission had never regarded a change to polypropylene as 'restructuring' under the aid code. ${ }^{31}$

These arguments can be summarised as follows. First, Deufil argued basically that its action was permitted because it was not prohibited by the code. Implicit in this argument was the applicant's view that the code had normative stability, if not (legally) binding force. The Commission countered this argument directly by suggesting that the fact that the applicant's behaviour was not prohibited by the code did not mean that it was permissible. In other words, soft law is not law at all; it can be changed any time because it is simply a more or less direct reflection of (changing) policy.

Second, emphasising the normative nature of the code, Deufil argued that its author, the Commission, was bound by its terms. This argument was not met by the Commission directly, most likely, it may be suggested, because of the obstacle posed by previous Court of Justice decisions. The leading case was Case $81 / 72$ Commission v Council 32 It involved a decision by the Council to apply for a three-year period a specific system of adjusting the salaries of Community staff. Advocate-General Warner had considered that the decision 'could have no legal effect, but should be regarded merely as a policy decision': '[n]otwithstanding its undeniable political importance, it was, in law, no better than a rope in sand'.33 The Court of Justice, however, held that the decision was binding on its author, and that the Council could not validly

31 See [1987] ECR 901 at 905, 907, 908 (Report for the Hearing). On the economic context, see also R. W. Shaw and S. A. Shaw, 'Excess Capacity and Rationalisation in the West European Synthetic Fibres Industry', Journal of Industrial Economics, 32, 2 December 1983, pp. 149-166.

32 [1973] ECR 575.

33 [1973] ECR 575 at $592,595$. 
adopt a Regulation which was not in accordance with its terms. ${ }^{34}$ Against this normative background, the Commission suggested in Deufil that the plaintiff was not entitled to claim a legitimate expectations that it should keep the aid, essentially because the plaintiff's interest was not worthy of protection. The Commission argued, inter alia that the aid was granted on the basis of false information, as the plaintiff had not indicated that the plant would be used partly for producing polyamide yarn. It also argued that the applicant knew that aid for such a purpose could not be paid without Commission authorisation. 35 In other words, even if soft law (though it is not hard law) may for the sake of argument be recognised as potentially having legal effects, it did not have any legal effects in the present circumstances.

The implicit contradictions in the Commission's two arguments were not addressed by either the Advocate-General or the Court of Justice. Instead, both the Advocate-General and the Court of Justice agreed that the aid code did not derogate from the Treaty, that it could nor legally do so, that it was not legally binding, and that it did not provide an independent basis for a negative decision by the Commission. They expressed these views differently, however, and with divergent implications.

According to Advocate-General Darmon,

'[a]lthough [the code] reflects the Commission's concept of Community interest and defines the line of conduct which it wishes to see Member States adopt, it in no way dispenses the latter, when they are consider-

34 The implications of the case law are however ambiguous: see John A Usher, 'General Course in European Community Law: The Continuing Development of Law and Institutions', Collected Courses of the Academy of European Law, Vol II, Book I (Dordrecht, Kluwer, 1992), pp 37-165 at 73-77; Jürgen Schwarze, (London, Sweet and Maxwell, 1992), pp. 1080-1085.

See [1987] ECR 901 at 911 . This argument was also perfectly consistent with German law, of which the plaintiff of course would have been well aware: du 25.5.1976. Art. 48(2)(2). See Francois Hubeau, 'Le principe de la protection de la confiance légitime dans la jurisprudence de la Cour de Justice des Communautés européennes', 19, 1, 1983, pp 143-162 at 145-146; see also Jürgen Schwarze, (Sweet and Maxwell, London, 1992), pp. 886-901, esp. 895-897. 
ing aid in a given case, from complying strictly with the terms of Articles 92 and 93. In other words, the 'guidelines' and the 'aid code' constitute a frame of reference, reinforcing, in particular, the obligation of notice laid down in Article 93(3) but they cannot be regarded as legally binding and thus capable of forming the basis of a negative decision by the institution.' 36

However, he granted that the code represented the Commission's definition of the general interest of the synthetic fibres sector, and more generally of the textile industry. Thus, in his view, the plaintiff could not claim to have been unaware that an investment that would enable it to increase production of polyamide, as well as of polypropylene, was contrary to this interest. Consequently, the code did not provide any basis for legitimate expectations. 37

Giving rather less normative force to the aid code, the Court of Justice largely followed the argument of the Commission. The Court of Justice stated '[t]he aid code constitutes guidelines setting out the course of conduct which the Commission intends to follow and with which it asks the Member States to comply in regard to aid to the synthetic yarns and fibres sector. It does not derogate from the provisions of Articles 92 and 93 of the Treaty, nor could it do so'.38 The Court of Justice held that the aid code, more specifically the fact that polypropylene yarns were not covered by the aid code, could not

7] ECR 901 at 920 (Opinion of Advocate-General Darmon.

38 [1987] ECR 901 at 927 [para 22]. This statement in part has been summarised, not altogether precisely, as ' $r$ r]ecently the European Court, in connection with the protection of legitimate expectation, has declared that the aid code contains indictative rules outlining the Commission's future policy. The Commission requires from the Member States that they stick to these rules in the sphere of state aid to that sector': K.C. Wellens and G.M. Borchardt, 'Soft Law in European Community Law', 14, 1989, pp 267-321 at 315-316. The slight but significant differences of wording and meaning between the summary and the Court of Justice's language tend to confer on the aid code a more legalistic tenor, and more legal effects, than the Court of Justice seemed to have intended. It is however worth noting that the article from which the summary is drawn was a translation from Dutch to English. In addition to exemplifying the difficulty of legal translation, these differences in words and meaning illustrate perhaps the role of legal scholarship ( ) in the extrapolation, though one hopes not the creation, of legal principles from judicial decisions. 
give rise to a legitimate expectation on the part of undertakings which could be relied on against an order issued by the Commission to the national authorities. 39

Instead of assuming the normative status of the code and saying to the applicant that 'your interest does not deserve protection', the Court of Justice thus accepted the Commission's view that the code was essentially a statement of policy, subject to alteration according to circumstances and at the discretion of its author. It may be suggested that the Court's view of the legitimacy of the applicant's claim might have influenced its decision to classify the code as policy rather than law. For example, the Court noted that the aid had actually resulted in a substantial increase in Deufil's capacity to produce polyamide yarn. 40 No such consideration concerning the code appears, however, on the face of the judgment. Consequently, in the Court's view, the aid code was designed perhaps to structure the exercise of Commission discretion with regard to products covered by the code. But it could not fetter the Commission's discretion under Articles 92 and 93 EEC to take decisions with regard to products which were not covered by the code. In other words, in the realm of policy, as distinct from the realm of law, what is not forbidden is not necessarily permitted.

\section{Commission Soft Law as the Context of Judicial Decision}

We can begin to tease out the implications of Deufil by examining the contexts, both normative and commercial, of the judicial decision. From the

39

40 Deufil applied for the aid to replace equipment capable of producing 3000 tonnes of polyamide yarn annually with equipment having an annual capacity of 5000 tonnes of polyamide and polypropylene yarn. According to information provided by Deufil to the Court, however, the capacity of the new equipment was 6000 tonnes and the intended conversion to polypropylene yarn had not yet been carried out in 1985 , with the result that 4191 tonnes of polyamide yarn and 1546 tonnes of polypropylene yarn were produced in 1985. [1987] ECR 901 at 922 [paras 2, 3]. 
standpoint of the Commission, the normative context of the case comprised two elements. The first element consisted of previous judgments by the Court of Justice. Prior to Deufil the Court of Justice had decided that Article 93(3) EEC was directly effective, 41 that this prohibition applied to any aid introduced by a Member State without having been duly notified, 42 and that the Commission need not fix any time limit when applying the Article 93(2) procedure to unnotified, implemented aid. 43

The second element consisted of a Commission soft law. On 24 November 1983 the Commission had issued a Communication regarding the recovery of illegally paid state aids. 44 The Communication informed potential recipients of state aids that they might have to refund any aid paid to them before the Commission had reached a final decision under Article 93(3). According to its terms, the Communication in turn stemmed a previous judgment by the Court of Justice, namely the Court's interpretation of Article 93(3) EEC in Loren $z^{45}$. It was intended to put into practice 'the possibility given to [the Commission] by the Court of Justice in its judgment of 12 July 1983 in Case $70 / 72^{\prime 46}$ of requiring Member States to recover from recipients illegally granted aid. It was published in the C series of the Official Journal.

The Commission Communication of November 1983 thus exemplified the absorption of a Court of Justice decision into Commission practice. By notifying potential recipients of state aids of likely Commission policy, it was intended

41 Case 78/76 v [1977] ECR 595.

42 Case 120/73 v [1973] ECR 1471.

43 Case 120/73 v [1973] ECR 1471; Case 173/73 v [1974] ECR 709. But see also Case $223 / 85$ v [1987] ECR 4617, judgment in which was delivered nine months after . Note that subsequently it was held that the fact that a state aid has not been notified does not entitle the Commission to decide that the aid is per se incompatible with the Common Market: Case C-301/87 v [1990] ECR I-307

Commission Communication [untitled], OJ 24.11.83 C318/3.

45 Case 120/73 v [1973] ECR 1471; the Communication also referred to Case 121/73 v [1973] ECR 1495, Case 122/73 v [1973] ECR 1511, and Case 141/73 v [1973] ECR 1527.

46 Commission Communication, OJ 24.11.83 C318/3; see Case 70/72 v [1973] ECR 813. 
to prevent litigation. In addition to being incorporated into Commission soft law norms, however, the judicial decision also had a direct influence on Commission practice. It marked the beginning of a period when the Commission pursued vigourously the principle of recovery of unnotified, implemented state aids. ${ }^{47}$

Deufil arose in this context of interrelated norms and institutional practice. The German Federal Government notified the Commission of the aid previously granted to Deufil less than three months after the Commission issued the Communication. In the subsequent judicial proceedings, however, none of the parties, the Advocate-General or the Court of Justice referred to the Communication. Yet it is scarcely credible that they were not aware of its contents. It is possible, indeed perhaps likely, that even Deufil knew of the Communication; one may suggest that, at least in the view of the Commission, the company certainly should have known. From the technical legal standpoint, however, there was no need to argue or decide the case on the basis of any soft law: as will be shown later, Deufil was entirely consistent with the previous case law of the Court. Yet, it may be suggested, the Commission's November 1983 Communication formed part of the political and policy context in which the case was argued, heard and decided. 48

47 Sylviane Morson, 'La récupération des aides octroyées par les Etats en violation du traité C.E.E.', 21, 3, 1990, pp 409-440 at 422 et seq., 427.

48 It is noteworthy that, nine months later, the Court of Justice in Case 223/85 v [1987] ECR 4617 held that the Commission's delay in giving a contested decision could establish a legitimate expectation so as to prevent the recovery of aid. Advocate-General Slynn (at 4643) treated the case as involving a failure on the part of the Commission to show due diligence, thus leading RSV to assume that the Commission did not object to the aid. The Court pointed to the Commission Communication of November 1983 with regard to the onus placed on economic operators to verify that proper procedures had been followed. See also Piet Jan Slot, 'Procedural Aspects of State Aids: The Guardian of Competition versus the Subsidy Villains?', 27, 1990, pp 741-760 at 754, 758. 


\section{Judicial Language As A Model For Commission Soft Law}

Similarly, the language of the judicial decision provided a model for later Commission soft law, that is, contributed to the social and legal process of its production and reproduction. Let us consider first whether the aid code actually influenced the result of the case. On the one hand, the company's argument concerning legitimate expectations was not accepted by the Court of Justice. In this respect, however, Deufil was in no way unusual. Arguments based on the principle of legitimate expectations are frequently advanced before the Court of Justice, but they are rarely successful. 49 On the other hand, the Commission was entitled in Deufil to order the recovery of the nonnotified aid. This result is also consistent with that of other cases, in which Commission soft law was entirely absent or no argument concerning soft law was made. 50

Taken together, these two points seem to suggest that Deufil in the aid code had little if any effect on the specific case result. If particular legal questions were raised by the aid code in particular or soft law in general, they were apparently not considered in detail by the Court of Justice. The Court of Justice simply 'looked through' the norms of soft law and reached, or at least

See generally Eleanor Sharpston, 'Legitimate Expectations and Economic Reality', 15, 1990, pp 103-160, esp. 132-133, 160; see also Francois Hubeau, 'Le principe de la protection de la confiance légitime dans la jurisprudence de la Cour de Justice des Communautés européennes', 19, 1, 1983, pp 143-162, Sylviane Morson, 'La récupération des aides octroyées par les Etats en violation du traité C.E.E.', 21, 3, 1990, pp 409440 at 429 . For the argument that in appropriate circumstances soft law should be capable of giving rise to legitimate expectations, see Melchior, 'Les communications de la Commission: Contribution à l'étude des actes communautaires non prévus par les traités', in vol. 2 (Paris: Nathan; Brussels: Labor, 1979), pp. 243-258 at 254, 257. With regard to the recovery of non-notified aid, however, the Court of Justice has held in 1989 that, where proceedings are brought against a Member State for failure to fulfil its obligation by not implementing a Commission decision requiring it to recover illegal aid and which it did not seek to have annulled, the only defence left to the Member State is to plead that it was absolutely impossible for it to implement the decision properly: Case 94/87 v [1989] ECR 175. This facts of the case occurred about the same time as those in even though the judgment was rendered almost two years later ( : 24 February 1987; : 2 February 1989).

\footnotetext{
See Sylviane Morson, 'La récupération des aides octroyées par les Etats en violation du
} traité C.E.E.', 21, 3, 1990, pp 409-440. 
stated, its decision on other, substantive grounds. In addition, even from the standpoint of legal commentators on the case, the aid code in Deufil seems to have been transparent, if not invisible. 51

In Deufil the Court of Justice stated that the aid code could not derogate from the Treaty. It also did not recognise the aid code as giving rise to legitimate expectations. This is not to say, however, that the Court of Justice denied all status to soft law in general, or even to the aid code in particular. Such a conclusion would be based only on a retrospective view, as if we were using the judgment as a rear-view mirror in order partially to reflect the past. Continuing the metaphor, let us instead, however, conceive of the judgment as a windscreen, in other words prospectively, through which to view the future. From this perspective, the description by the Court of Justice of the aid code in Deufil had real effects.

On 22 December 1988 the Commission took a decision to implement, on the basis of Article 93(1) EEC, a Community framework on State aids to the motor vehicle industry. The act was not a formal decision in the sense of Article 189 EEC. The measure had been examined at a multilateral meeting by the representatives of the Member States. 52 The Commission on 31 December 1988 informed the Member States of the decision by letter. The framework was subsequently published in the $\mathrm{C}$ series of the Official

51 The doctrinal importance of has been described as being, first, in the reminder by the Court of Justice that the notification procedure is designed partly to avoid endangering any legitimate expections, and, second, and more precisely, in the conclusion that 'a subsidy granted without the required notification cannot form a valid basis for a legitimate expectation on the part of the recipient of the aid which is capable of protection.' See, respectively, Sylviane Morson, 'La récupération des aides octroyées par les Etats en violation du traité C.E.E.', 21, 3, 1990, pp 409-440 at 429, n. 114; and Jürgen Schwarze, (Sweet and Maxwell, London, 1992), p. 1075.

52 Community Framework on State Aid to the Motor Vehicle Industry (89/C123/03), OJ 18.5.89 C123/3 at 3 [paragraph 4]. 
Journal. ${ }^{53}$ It was expressed as a proposal by the Commission to the Member States. Acting under Article 93(3) EEC, the Commission proposed that, as from 1 January 1989, and in accordance with specified rules, the Member States notify significant cases of state aid in the motor vehicle sector.

Despite its soft law character, the measure was treated seriously by the parties. It provoked a very formal reaction from the German Government, which 'formally informed' the Commission of its decision not to apply the Community framework and of its reasons for this decision. 54 In an equally formal reply, the Commission then informed the German Government by letter that 'if ...[the German authorities] failed to ... [reconsider their position], it would be forced to initiate the Article 93(2) procedure in respect of all aid schemes in operation in Germany for the benefit of the motor vehicle industry, with the objective of enforcing the application of the framework.'55

The Commission argued that it was justified in introducing new restrictions on existing state aid schemes. In support, it adduced the Deufilcase. It stated that:

'The Commission does not accept the argument that, given the independence of the Member States as concerns regional and general aid schemes, it is not justified in introducing new restrictions on existing schemes. The Court of Justice stated in its judgment of 24 February 1987 in Deufil (case 310/85) that a framework on State aid in a particular sector provides guidelines setting out the course of conduct which the Commission intends to follow and with which it asks Member States to comply when granting aid in the sector in question. The Court considered that such a framework does not contain derogations from Articles 92 and 93. The assessment by the Commission of individual awards under existing regional and general

53 Community Framework on State Aid to the Motor Vehicle Industry (89/C123/03), OJ 18.5.89 C123/3.

54 Ibid., preamble, fourth recital, OJ $20.7 .90 \mathrm{~L} 188 / 85$.

55 Ibid., preamble, fifth recital, OJ L188/55 at L188/55 and L188/56 (emphasis added). 
aid schemes will therefore always be based on the provisions of Articles 92 and 93.'56

For our purposes, this statement has a two-fold importance.

First, it marks the creation of Commission soft law on the basis of judicial language that did not form part of, or at least was not necessary for, the prior specific judicial decision (dispositif). Indeed, as already seen, the Court of Justice in Deufil treated the aid code as transparent. Yet the Commission absorbed this judicial language, incorporating it as part of the raw material of the Commission's own working practices. In doing so, the Commission in effect borrowed a typical tool of the Court of Justice: namely the use in later situations of 'significant principles which, expressed in key paragraphs of the judgment, encompass not only the particular case but also potential future situations'.57

Second, the Court's language in Deufil was limited to a specific case. On this basis, however. the Commission has created a general model of (Commission) soft law. In Deufil the Court of Justice referred simply to the textiles 'aid code' and to 'aid to the synthetic yarns and fibres sector', 58 not to 'a framework on State aid in a particular sector' or to 'when granting aid in the sector in question'. Similarly, the Court treated only the question as to whether the textiles aid code derogated from Articles 92 and 93 EEC, rather than the relation to the Treaty of 'such framework[s]' in general. It was concerned, necessarily, with the individual case. The Commission interpreted the judgment as referring, however, not to an isolated instance of soft law,

56 Commission Decision of 21 February 1990 amending German aid schemes for the motor vehicle industry (90/381/EEC), OJ 20.7.90 L188/55 at L188/58.

57 Francis Snyder, 'The Effectiveness of European Community Law: Institutions, Processes, Tools and Techniques', 56, 1993, pp 19-54 at 50.

58 Case 310/85 v [1987] ECR 901 at 927 [paragraph 22]. 
still less a particular sector, but rather to an exemplar, a normative model of soft law. By generalising from the language of the Court of Justice in the Commission thus used the judgment to legitimate further soft law, namely analogous codes in other sectors.

\section{From Soft Law to Hard Law by Administrative Decision}

Soft law, once elaborated, may sometimes be transformed into hard law. The transformation usually occurs by judicial decision or legislation. Deufil illustrates the first alternative, though it represents a negative case. The Court of Justice did not view the aid code as hard law, it declined to grant it any legal effects, and it treated it as merely transparent. An example of the second alternative is the current discussion concerning the enactment as a regulation of a measure which began as a Commission code of conduct on the report of fraud against the Community. ${ }^{59}$ In addition, however, in the Community system soft law may be transformed into hard law by administrative decision. Such acts are taken in accordance with Article 189 EEC. In principle administrative decisions are discrete, but in Community practice it is not always easy to distinguish them clearly from general legislation. 60

The protest by Germany concerning the application by the Commission of the framework on State aids to the motor vehicle industry led to a series of meetings between the two parties. The discussions did not, however, result in German compliance. Consequently, on 21 February 1990 the Commission adopted a formal Decision concerning the application to Germany of the

59 Code of conduct on the implementing provisions for Article 23(1) of Council Regulation (EEC) No 4253/88 relating to irregularities and the organisation of an information system for irregularities, OJ 1990 C220/3; see also Case C-303/90 v [1991] ECR I-5315.

60 See A.G. Toth (ed.), volume I: (Oxford: Clarendon Press, 1991), pp 157-158. 
Community framework on state aid to the motor vehicle industry. ${ }^{61}$ For the present purposes the Decision is of interest in three respects.

First, even discounting for context and hindsight, it reveals the Commission's view of the state aids framework. As described in the Decision, the framework ' required prior notification of all State aid measures granted within the scope of approved aid schemes to motor vehicle manufacturers where the project cost exceeds ECU 12. million, entered into force on 1 January 1989 and $[w a] s$ valid for two years.' 62 The Commission's objective was 'in particular to secure the modification of all existing aid schemes applicable in the motor vehicle sector and to make it compulsory to give prior notification of individual awards in accordance with the criteria laid down in the framework, especially the criterion concerning project costs exceeding ECU 12 million.' 63 This version, gloss or interpretation of the soft law language is much more legalistic. formal and coercive than that of the original text.

Second, the Decision shows the extent to which this legalistic conception of the framework was shared by the two parties. During the prior negotiations, both the German government and the Commission viewed the framework as a potential basis of further measures, norms and possibly obligations. The German authorities argued inter alia that the framework would be used 'to enforce measures which are motivated by industrial policy pursuant to Articles 92 and $93 \mathrm{EEC}^{\prime}$, thus constituting an abuse of these Treaty articles. ${ }^{64}$ In their view, investment decisions should be left to the market rather than being 'regulated by means of a central control system', viz. the

61 Commission Decision of 21 February 1990 amending German aid schemes for the motor vehicle industry (90/381/EEC), OJ 20.7.90 L188/55.

62 Commission Decision 90/381/EEC, preamble, first recital, OJ 20.7.90, L188/55 at L188/55 (emphasis added).

63 Ibid., preamble, second recital, OJ L188/55 at L188/55 (emphasis added).

64 Ibid., preamble, ninth recital, subpara 3, OJ 20.7.90 L188/55 at L188/56 (emphasis added). 
framework. 65 For its part, the Commission referred, inter alia to 'the strict discipline imposed by the framework'.66 After citing the judgment of the Court of Justice in Deufil the Commission pointed out that 'even if the framework in question is simply a recommendation the German authorities have nevertheless already had 14 months in which to amend their laws in order to comply with the framework.' 67 The parties disagreed on the need for Commission co-ordination of the formulation of policy with Member States, as well as on whether the Community had legal competence to adopt an industrial policy. They shared, however, the view that the state aids framework had a normative force. The framework may have been soft law, but it was distinguished from hard law only by a very fine line.

Third, and most importantly, the February 1990 Decision transformed soft law into hard law. Not only was it designed to enforce the soft law framework; it also incorporated directly some of its terms. From the legal standpoint, as required by Article 190 EEC, the Decision was based on the Rome Treaty, in casu the first subparagraph of Article 93(2) EEC. However, its essential substantive elements included the Community framework. Thus, the Decision required Germany to notify the Commission of all aid measures above a specified amount to undertakings in the motor vehicle sector as defined in the framework. Notification was to be effected in conformity with

65 Ibid., preamble, ninth recital, subpara 4, OJ 20.7.90 L188/55 at L188/56.

66 Ibid., preamble, eleventh recital, subpara 3, OJ 20.7.90 L188/55 at L188/57 (emphasis added). The Decision states that

'[t]he Commission fully shares the view that investment decisions should be left to the market and not be transferred to an administrative authority. In this context it is evident that the framework is not designed to put the Commission in the role of guiding investment decisions in specific directions but, on the contrary, to that such decisions are indeed taken by the investors concerned, that any State aid is consistent with the common interest as established by the Treaty, and that the aid is in strict proportion to the problems which they intend to resolve. Indeed, the Commission seeks to by means of the framework that investors are not influenced in their decisions by the availability of unilateral funds. (Ibid., preamble, eleventh recital, subparagraph 4, OJ 20.7.90 L188/55 at L188/57 (emphasis added)).

67 Ibid., preamble, eleventh recital, subparagraph 12, OJ 20.7 .90 L188/55 at L188/59 (emphasis added). 
the requirements laid down in the framework. Germany was also to provide annual reports as required by the framework. 68 In this way Commission soft law was enforced by being incorporated into hard law. The Commission Decision thus represents a further transformation of the Court's language, building upon its earlier elaboration by the Commission into a more general normative model, but incorporating its implications into a legally binding Decision.

\section{Soft Law, Efficiency, Legality And Legitimacy}

Commission soft law provides an ideal vehicle for examining the working practices of the Commission and the Court of Justice, as well as the relations between these two institutions. The Deufil saga is an especially illuminating example. It shows how soft law may form part of the implicit context of judicial decisions, how judicial language can be elaborated and generalised in the form of soft law, and how soft law, based partly on a court judgment, is transformed into hard law by administrative decision.

In the Community political and legal system the Commission and the Court of Justice have a fundamental place. Except in legal terms, however, their roles are not always clearly defined. 69 Yet from a contextual standpoint any analysis of these institutions and relations between them requires that each institution should be taken seriously, for example both as a legal and as a political

. Article 1, OJ 20.7.90 L188/55 at L188/60.

69 The classic article is Pierre Pescatore, 'L'exécutif communautaire: Justification du quadripartisme institué par les traités de Paris et de Rome', 1978, 387-406. Inter-institutional relations are often discussed in terms of institutional balance but this concept is relatively indeterminate. See Roland Beiber, "The Settlement of Institutional Conflicts on the Basis of Article 4 of the EEC Treaty', 21, 1984, pp 505-523. On the Commission, see, e.g., Karlheinz Neunreither, 'Transformation of a Political Role: Reconsidering the Case of the Commission of the European Communities', 10, 3, March 1972, pp 233-248; Sabino Cassese and Giacinto della Cananea, 'The Commission of the European Communities: the Administrative Ramifications of its Political Development (1957-1967), in 4: (Nomos, Baden-Baden, 1992), pp 75-94. 
institution. One approach to doing so is to note that the Commission and the Court of Justice share two significant features. The first feature applies to all organisations: 'survival is necessary for effectiveness', and 'legitimacy is necessary for survival'. 70 The second feature is specific to the Community system: more than other Community institutions, the Commission and the Court of Justice have been concerned, by and large, to promote normative (and decisional) supranationalism. 71 Viewed in the context of the Maastrict Treaty debate, these features render the lessons of the Deufil saga salient and problematic. In the course of working together, the Commission and the Court of Justice create, maintain, ignore, negate or transform Commission soft law. How they do so may not affect their survival, but it is likely to influence directly their effectiveness and legitimacy.

In the Deufil saga soft law served two purposes. On the one hand, it provided a way of structuring Commission discretion. This is a classic function of soft law, 72 which may also be unproblematic in the Community system. With this purpose in mind, it has been suggested that recourse to soft law is justified, but that soft law should be used cautiously: economic integration and judicial protection of the individual need to be finely balanced. ${ }^{73}$ The suggestion is pertinent, especially since current Commission policy is to make increasing use of communications to encourage greater transparency and to channel participation in decision-making. ${ }^{74}$ As Deufil illustrates, however, it is necessary

70 See Lawrence B. Mohr, 'The Concept of Organizational Goal ', 67, June 1973, pp 470481.

71 See Joseph H.H. Weiler, 'The Community System: The Dual Character of Supranationalism', 1, 1981, pp 267-306; see also Joseph H.H. Weiler, 'The Transformation of Europe', 100, June 1991, pp 2403-2483.

72 See, for example, Robert Baldwin and John Houghton, 'Circular Arguments: The Status and Legitimacy of Administrative Rules', 1986, pp 239-284.

73 K.C. Wellens and G.M. Borchardt, 'Soft Law in European Community Law', 14, 1989, pp 267-321 at 320-321.

74 See Commission of the European Communities, 'An Open and Structured Dialogue between the Commission and Special Interest Groups', Communication from the Commission, SEC(92) 2272 final (Brussels, 2 December 1992); Commission of the 
to go further. Even if Deufil had used the aid for purposes entirely outside the code, it might still have lost the case. The view expressed by the Court of Justice that the interpretative soft law was policy, not law, could have tilted the scales towards administrative discretion and economic integration, instead of towards legitimate expectations and judicial protection.

On the other hand, the soft law in Deufil served as a substitute for legislation. This use of soft law is frequent in international relations, where legal rules may be difficult to promulgate and soft law often serves as 'a compromise between sovereignty and order'.75 Especially in the light of the Maastricht Treaty, it could be suggested that the Community system is moving gradually towards a similar pattern. Soft law might then be viewed as a useful form of regulation, a means of co-ordinating relations among Member States and of balancing unity and diversity. It would provide a feasible alternative to minimum harmonisation, regulatory competition or opting-out. It could represent a suitable compromise to settle disputes, whether between the Community and the Member States, the Member States themselves or sometimes different parts of the Commission.76 As with other forms of regulation in the Community, thus contrasting with much of international law, soft law would also be subject ultimately to judicial supervision.

In the Community system, however, at least as it stands at the moment, this use of soft law inevitably raises issues of legitimacy. In Deufil Commission

European Communities, 'Increased Transparency in the Work of the Commission', Communication from the Commission, SEC(92) 2274 final (Brussels, 2 December 1992). Both, it should be noted, are informative rather than interpretative communications.

75 Michael Bothe, 'Legal and Non-Legal Norms - A Meaningful Distinction in International Relations', 11, 1980, pp 65-95 at 90.

76 An example of the third category is Commission Recommendation 90/109 on the transparency of banking conditions, OJ 1990 L67/39. I am grateful to Stephen Weatherill for this example, as well as for the more general comparison between international law and trends in Community law. 
soft law was used to fill the 'gap' that resulted from the failure of other institutions, namely the Council, to enact implementing legislation. 77 'If the non-legal norm is hailed because it circumvents the obstacles involved in the creation of a legal norm, one must not forget that a number of these obstacles, unpleasant as they may appear to a particular decision-maker, have a justification of their own'.78 In these circumstances, it is not simply the choice of a specific type of act which is in question: the form of decisionmaking, the extent of popular participation, and political legitimacy are also at issue. The use of soft law thus raises in a very acute way the problematic relationship between efficiency, legality and legitimacy.

Though most significant regarding state aids perhaps, the use of soft law in this way is unlikely to be limited to this field. Instead, it may be hypothesised, ${ }^{79}$ it is simply an indication of a more general phenomenon within the Community legal system, namely a shift from conditional programmes to purposive programmes. The design of regulatory policy thus has a direct and immediate influence on the use of law. This process is common to the legal systems of all industrial societies. It raises especially difficult issues in the Community system, however, because an increase in economic integration and the substantial Europeanisation of policy-making have not been accompanied by the development of widely accepted political institutions.

In the United States legal scholars have argued for a partnership between regulatory agencies and courts. Not only would the partnership control regu-

77 On the refusal of the Council to adopt regulations on the basis of Article 94 EEC, see Erik J. Pijnacker Hordijk, 'Judicial Protection of Private Interests under the EEC Competition Rules relating to State Aids', 1, 1985, pp 67-98 at 70-77, 96-97; Piet Jan Slot, 'Procedural Aspects of State Aids: The Guardian of Competition versus the Subsidy Villains?', 27, 1990, pp 741-760 at 741-744, 759-760; Sylviane Morson, 'La récupération des aides octroyées par les Etats en violation du traité C.E.E.', 21, 3, 1990, pp 409440 at 440; Enzo Moavero Milanesi, 'Partecipazione dello Stato nelle Imprese e Disciplina Comunitaria degli Aiuti Pubblici', 1990, pp 515-576 at 530, 573-575.

78 Michael Bothe, 'Legal and Non-Legal Norms - A Meaningful Distinction in International Relations', 11, 1980, pp 65-95 at 93.

79 I am grateful to Christian Joerges for this point. 
latory bureaucracies; it would also enable agencies to pursue worthwhile social objectives. ${ }^{80}$ As Deufil suggests, however, in the Community system such a partnership may place an intolerably heavy burden on the Commission and the Court of Justice, viewed as both legal and political institutions. In addition, it may increase private rather than public control of regulation, encourage defensive decision-making by regulatory agencies and make courts the ultimate arbiters of policy. 81

The example of soft law thus illuminates the specific features of the Community's system and its lack of strong institutions for broad politicai participation at Community level. For example, the Community differs significantly from national administrative systems. On the one hand, in national administrations the use of soft law may have relatively little effect on the constitutionally established relations between institutions. In the Community, however. Commission soft law tends not simply to channel the Commission's use of its implementing powers, but also, and perhaps more problematically, to expand the Commission's role in relation to other institutions. On the other hand, national administrative use of soft law occurs within a framework of legislation enacted by elected representatives. This contrasts sharply with the position in the Community, especially when, as in Deufil, soft law is used to fill perceived gaps in the Community political process.

\section{Conclusion}

A trend in the Community towards the increasing use of soft law would be consistent with patterns of development in national administrations and inter-

80 See Martin Shapiro, (Athens, Georgia: The University of Georgia Press, 1988), pp 127; see also Giandomenico Majone, 'Controlling Regulatory Bureaucracies: Lessons from the American Experience', manuscript to be published.

81 See Robert Baldwin and Keith Hawkins, 'Discretionary Justice: Davis Reconsidered', 1984, pp 570-599 at 597-598. 
national organisations. 82 The institutional and political context of the Community differs profoundly, however, from these other contexts. For this reason, it is important to assess carefully the use of soft law in the Community system. Of special importance are the interpretation of the concept of subsidiarity as expressed in the Maastricht Treaty and its practical implications for the use of different types of legislative acts. Otherwise, the working practice of Community institutions may simply increase the contradictions between efficiency, legality, and legitimacy.

82 A pertinent example is the 'Circulaire du 22 septembre 1988 relative à la définition des politiques de la France en matière européenne', 48, octobre-décembre 1988, pp 536-537. See generally Ganz, (London, Sweet \& Maxwell, 1987); Cliquennois, 'Que reste-t'il des directives? A propos du vingtième anniversaire de l'arrêt ', (1992) 20 3; Chiti, 'Circolare I: Circolare amministrativa', Vol VI (Rome: Istituto della Enciclopedia Italiana, 1988); OECD Council Recommendation on the Application of the Polluter Pays Principle to Accidental Pollution, (1989) 28 ILM 1320; OECD Guidelines for Multinational Enterprises (1976) 15 ILM 967. 


\section{Bibliography}

Administrative Review Council. 1992. Rule Making by Commonwealth Agencies, Report to the Attorney General, Report No. 35 (Canberra: Australian Government Publishing Service, 1992)

Baldwin, Robert, and John Houghton, 1986. 'Circular Arguments: The Status and Legitimacy of Administrative Rules', Public Law, pp 239-284

Baldwin, Robert and Keith Hawkins, 1984. 'Discretionary Justice: Davis Reconsidered', Public Law, pp 570-599

Burrows, Noreen, T.C. Daintith, Leigh Hancher, Francis Snyder and John Usher, 1991. 'United Kingdom Report', in Jürgen Schwarze, Inge Govaere. Frédérique Hélin and Peter Van de Bossche (eds.), The 1992 Challenge at National Legal: Reports and Conference Proceedings 1990 (Baden-Baden Nomos, 1991)

Bieber, Roland, 1984. 'The Settlement of Institutional Conflicts on the Basis of Article 4 of the EEC Treaty', Common Market Law Review, 21, pp 505 523.

Bothe, Michael, 1980. 'Legal and Non-Legal Norms - A Meaningful Distinction in International Relations', Netherlands Yearbook of International Law, 11, pp 65-95

Cassese, Sabino, and Giacinto della Cananea, 1992. 'The Commission of the European Communities: the Administrative Ramifications of its Political Development (1957-1967), in Jahrbuch für Europäische Verwaltungsgeschichte 4: Die Anfänge der Verwaltung der Europäischen Gemeinschaft (Baden-Baden: Nomos), pp 75-94

Chiti, Mario, 1988. 'Circolare I: Circolare amministrativa', Enciclopedia Giuridica Vol VI (Rome: Istituto della Enciclopedia Italiana)

'Circulaire du 22 septembre 1988 relative à la définition des politiques de la France en matière européenne', Revue francaise d'Administration publique, 48, octobre-décembre 1988, pp 536-537

Cliquennois, Martine, 1992 'Que reste-t'il des directives? A propos du vingtième anniversaire de l'arrêt Crédit foncier de France', L'Actualité juridique - Droit administratif, 20, pp 3-11 
Commission of the European Communities, 1979. 'Communication from the Commission concerning the Consequences of the Judgment given by the Court of Justice on 20 February 1978 in Case 120/78 ('Cassis de Dijon'), OJ 1979 $\mathrm{C} 256 / 2$.

Commission of the European Communities, 1983. 'Commission Communication' [untitled], OJ 24.11.83 C318/3

Commission of the European Communities, 1985. 'Completing the Internal Market' (White Paper from the Commission to the European Council, Milan, 28-29 June 1985), COM(85)310 final (1985)

Commission of the European Communities, 1989. 'Community Framework on State Aid to the Motor Vehicle Industry $(89 / \mathrm{C} 123 / 03)$ ', OJ $18.5 .89 \mathrm{C} 123 / 3$

Commission of the European Communities, 1992a. 'The principle of subsidiarity: Communication of the Commission to the Council and the European Parliament', SEC(92)1990 final (Brussels, 27 October)

Commission of the European Communities, 1992b. 'An Open and Structured Dialogue between the Commission and Special Interest Groups', Communication from the Commission, SEC(92) 2272 final (Brussels, 2 December)

Commission of the European Communities, 1992c. 'Increased Transparency in the Work of the Commission', Communication from the Commission, SEC(92) 2274 final (Brussels, 2 December)

Dehousse, Renaud, Christian Joerges, Giandomenico Majone and Francis Snyder in collaboration with Michelle Everson, 1992. 'Europe after 1992: New Regulatory Strategies', EUI Working Paper LAW No. 92/31, European University Institute, Florence

Easson, Alex, 1989. 'Legal Approaches to European Integration: The Role of Court and Legislature in the Completion of the European Common Market', Revue d'Intégration EuropéennelJournal of European Integration, 12, 2-3, pp 101-119

Ehrlich, Isaac and Richard A. Posner, 1974. 'An Economic Analysis of Legal Rulemaking', The Journal of Legal Studies, 3, 1, pp 257-286

European Council, 1992. 'Conclusions of the Presidency', Edinburgh, 11-12 December

Ganz, Gabrielle, 1987. Quasi-Legislation (London: Sweet \& Maxwel1) 
Giddens, Anthony, 1989. 'A Reply to My Critics', in David Held and John B. Thompson, Social Theory of Modern Societies: Anthony Giddens and His Critics (Cambridge: Cambridge University Press) pp 253-259

Giddens, Anthony, 1975. New Rules of Sociological Method (London: Hutchinson)

Hubeau, François, 1983. 'Le principe de la protection de la confiance légitime dans la jurisprudence de la Cour de Justice des Communautés européennes', Cahiers de Droit Européen, 19, 1, pp 143-162

Lenaerts, Koenraad, 1991. 'The Development of the Judicial Process in the European Community after the Establishment of the Court of First Instance', Collected Courses of the Academy of European Law 1990, Vol I, Book I (Dordrecht: Kluwer), pp 53-113

Majone, Giandomenico, 1993. 'Controlling Regulatory Bureaucracies Lessons from the American Experience', manuscript to be published.

Mattera, Alfonso, 1990. Le marché unique européen: Ses règles, son fonctionnement (Paris: Jupiter, 2nd ed.)

Melchior, Michel, 1979. 'Les communications de la Commission: Contribution à l'étude des actes communautaires non prévus par les traités', in Mélanges Fernand Deinousse, vol. 2 La Construction européenne (Paris: Nathan; Brussels: Labor), pp 243-258

Moavero Milanesi, Enzo, 1990. 'Partecipazione delle Stato nelle Imprese e Disciplina Comunitaria degli Aiuti Pubblici', Rivista di Diritto Europeo, pp 515-576

Mohr, Lawrence B., 1973. 'The Concept of Organizational Goal', American Political Science Review', 67, June, pp 470-481

Morson, Sylviane, 1990. 'La récupération des aides octroyées par les Etats en violation du traité C.E.E.', Revue Trimestrielle de Droit Européen, 21, 3, pp 409-440

Neunreither, Karlheinz, 1972. 'Transformation of a Political Role: Reconsidering the Case of the Commission of the European Communities', Journal of Common Market Studies, 10, 3, March, pp 233-248

OECD, 1989. Council Recommendation on the Application of the Polluter Pays Principle to Accidental Pollution, International Legal Materials, 28, p 1320 
OECD, 1976. Guidelines for Multinational Enterprises, International Legal Materials, 15, p 967

Pescatore, Pierre, 1978. 'L'exécutif communautaire: Justification du quadripartisme institué par les traités de Paris et de Rome', Cahiers de Droit Européen, pp 387-406

Pescatore, Pierre, 1983. 'La carence du legislateur et le devoir du juge', in Rechtsvergleichung, Europarecht und Staatenintegration, Gedächtnisschrift für L.-J. Constantinesco (Saarbrücken: Europa Institut), PP 559-580

Pijnacker Hordijk, Erik J., 1985. 'Judicial Protection of Private Interests under the EEC Competition Rules relating to State Aids', Legal Issues of European Integration, 1, pp 67-98

Rasmussen, Hjalte, 1986. On Law and Policy in the European Court of Justice (Dordrecht: Martinus Nijhoff)

Reale, Mariacristina, 1989-90. 'Le comunicazioni interpretative della Commissione della Comunità Europea', Tesi di Laurea in Diritto delle Comunità Europea, Università degli Studi di Bologna, Sessione invernale

Reale, Mariacristina, 1992. 'Uno Strumento di "Soft Law" Comunitario', Impresa e Stato, 18, Giugno, pp 26-30

Schwarze, Jürgen Schwarze, 1992. European Administrative Law (London: Sweet and Maxwell)

Shapiro, Martin, 1988. Who Guards the Guardians? (Athens, Georgia: The University of Georgia Press, 1988)

Sharpston, Eleanor, 1990. 'Legitimate Expectations and Economic Reality', European Law Review, 15, pp 103-160

R.W.Shaw and S.A.Shaw, 'Excess, Capacity and Rationalisation in the West European Synthetic Fibres Industry', Journal ofIndustrial Economics, 32, 2, December 1983, pp.149-166

Slot, Piet Jan, 1990. 'Procedural Aspects of State Aids: The Guardian of Competition versus the Subsidy Villains?', Common Market Law Review, 27 , pp 741-760

Snyder, Francis, 1990. New Directions in European Community Law (London: Weidenfeld \& Nicolson) 
Snyder, Francis, 1993a. 'The Effectiveness of European Community Law: Institutions, Processes, Tools and Techniques', Modern Law Review, 56, pp 19-54

Snyder, Francis, 1993b. European Community Law, 2 volumes. (Aldershot: Dartmouth Publishing Company, 1993)

'Subsidiarité: Nouveau code de conduite pour construire l'Europe', EUROinfo (Commission des Communautés Européennes, Bulletin mensuel du Bureau en Belgique), 172, février 1993, pp 12-13

Toth, A.G. (ed.), 1991. The Oxford Encyclopaedia of European Community Law, volume I: Institutional Law (Oxford: Clarendon Press)

Usher, John A., 1992. 'General Course in European Community Law: The Continuing Development of Law and Institutions', Collected Courses of the Academy of European Law, Vol II, Book I (Dordrecht: Kluwer), pp 37-165

Vergès, Jean, 1980. 'De quelques méthodes de développement institutionnel des Communautés européennes', in Mélanges offerts à Paul Reuter: Le droit international: unité et diversité (Paris: Pedone), pp 501-517

Waterhouse, Keith, 1993. 'When guidelines are the limit', Daily Mail (Birmingham), Monday, January 4, p 8

Weiler, Joseph H.H., 1981. "The Community System: The Dual Character of Supranationalism', Yearbook of European Law, 1, pp 267-306

Weiler, Joseph H.H., 1991. 'The Transformation of Europe', Yale Law Journal, 100, June, pp 2403-2483

Wellens, K.C. and G.M. Borchardt, 1989. 'Soft Law in European Community Law', European Law Review, 14, pp 267-321

Wilke, Marc and Helen Wallace, 1990. Subsidiarity: Approaches to Powersharing in the European Community, RIIA Discussion Papers 27 (London: The Royal Institute of International Affairs) 


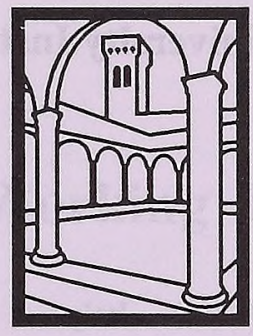

EUI

WORKING

PAPERS

EUI Working Papers are published and distributed by the European University Institute. Florence

Copies can be obtained free of charge

- depending on the availability of stocks - from:

The Publications Officer

European University Institute

Badia Fiesolana

I-50016 San Domenico di Fiesole (FI)

Italy 


\title{
Publications of the European University Institute
}

To

\author{
The Publications Officer \\ European University Institute \\ Badia Fiesolana \\ I-50016 San Domenico di Fiesole (FI) - Italy \\ Telefax No: $+39 / 55 / 573728$
}

From

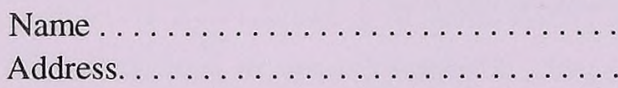

$\square$ Please send me a complete list of EUI Working Papers

$\square$ Please send me a complete list of EUI book publications

$\square$ Please send me the EUI brochure Academic Year 1994/95

$\square$ Please send me the EUI Research Review

Please send me the following EUI Working Paper(s):

No, Author

Title:

No, Author

Title:

No, Author

Title:

No, Author

Title:

Date

Signature 


\section{EUI Working Papers as from 1990}

As from January 1990, the EUI Working Papers Series is divided into six sub-series, each series is numbered individually (i.e. EUI Working Paper HEC No. 90/1; ECO No. 90/1; LAW No. 90/1; SPS No. 90/1; EPU No. 90/1; ECS No. 90/1). 


\section{Working Papers in Law}

LAW No. 90/1

David NELKEN

The Truth about Law's Truth

LAW No. 90/2

Antonio CASSESE/Andrew

CLAPHAM/Joseph H. H.

WEILER

1992 - What are our Rights?

Agenda for a Human Rights

Action Plan

LAW No. 90/3

Sophie PAPAEFTHYMIOU

On a "Constructivist

Epistemology of Law"

LAW No. 90/4

Joachim WÜRMELING

Legislativer Trilog im Institutionellen Dreieck der Europäischen Gemeinschaft. Das Verfahren der Zusammenarbeit nach Artikel

149 Absatz 2 EWGV.

\section{LAW No. $90 / 5$}

Renaud DEHOUSSE

Représentation territoriale et représentation institutionnelle: réflexions sur la réforme du Sénat belge à la lumière des expériences étrangères

\section{LAW No. $90 / 6$}

J. KORTE (ed.)/

A. E. KELLERMANN/

W. M. LEVELT-OVERMARS/

F. H. M. POSSEN

Primus Inter Pares: The European

Court and National Courts.

The Follow-up by National Courts of Preliminary Rulings ex Art. 177 of the Treaty of

Rome: A Report on the Situation

in the Netherlands

LAW No. 90/7

Reiner GRUNDMANN

Luhmann Conservative, Luhmann

Progressive

\section{LAW No. $90 / 8$}

Bruno DE WITTE

The Integrated Mediterranean

Programmes in the Context of

Community Regional Policy*

LAW No. 90/9

Anne-Laurence FAROUX

Le Ministère de la Culture en

France: Création et organisation

$$
\text { 深棌 }
$$

LAW No. 91/10

Christian JOERGES (ed.)

European Product Safety, Internal

Market Policy and the New Approach to

Technical Harmonisation and Standards

Vol. 1

Christian JOERGES

The Juridification of Product

Safety Policy*

\section{LAW No. 91/11}

Christian JOERGES (ed.)

European Product Safety. Internal

Market Policy and the New Approach to Technical Harmonisation and Standards

Vol. 2

Gert BRÜGGEMEIER/

Hans-W. MICKLITZ

Product Safety Legislation

in France and in the United

Kingdom*

*out of print 


\section{LAW No. 91/12}

Christian JOERGES (ed.)

European Product Safety, Internal

Market Policy and the New Approach to

Technical Harmonisation and Standards

Vol. 3

Gert BRÜGGEMEIER/

Josef FALKE/Christian JOERGES

Product Safety Legislation in the

Federal Republic of Germany and in the United States*

\section{LAW No. 91/13}

Christian JOERGES (ed.)

European Product Safety, Internal

Market Policy and the New Approach to

Technical Harmonisation and Standards

Vol. 4

Josef FALKE/Christian JOERGES

"Traditional" Harmonisation

Policy, European Consumer Protection Programmes and the New Approach*

\section{LAW No. 91/14}

Christian JOERGES (ed.)

European Product Safety, Internal

Market Policy and the New Approach to

Technical Harmonisation and Standards

Vol. 5

Christian JOERGES/

Hans-W. MICKLITZ

Internal Market and Product

Safety Policy*

\section{LAW No. 91/15}

\section{Christian JOERGES}

Markt ohne Staat? Die

Wirtschaftsverfassung der Gemeinschaft und die Renaissance der regulativen Politik*

\section{LAW No. 91/16}

Erk Volkmar HEYEN

Systemic Interference and Social Segmentation of Scientific Legal Discourse: Some Theoretical Perspectives and Empirical Results in the Field of Continental Administrative Law

\section{LAW No. 91/17} Andrea SCHULZ

Verfassungsrechtliche Grundlagen der auswärtigen Kulturpolitik

\section{LAW No. $91 / 18$}

Hans-W. MICKLITZ

Internal Legal Instruments for the Regulation and Control of the Production and Use of Chemicals and Pesticides*

\section{LAW No. $91 / 19$}

Hans Ulrich Jessurun

d'OLIVEIRA

Class Actions in Relation to Cross-Border Pollution.

A Dutch Perspective*

LAW No. 91/20

Luis María DÍEZ-PICAZO/ Marie-Claire PONTHOREAU

The Constitutional Protection of Social Rights: Some Comparative Remarks

$$
\text { 米濚米 }
$$

\section{LAW No. 92/21}

Aidan O'NEILL/Jason COPPEL

The European Court of Justice

Taking Rights Seriously? 
LAW No. $92 / 22$

Massimo LA TORRE

Linguaggio giuridico e realtà

sociale. Note sulla critica

realistica del concetto di diritto

soggettivo

\section{LAW No. 92/23}

Renaud DEHOUSSE

Integration v. Regulation?

Social Regulation in the European Community

LAW No. $92 / 24$

José Engrácia ANTUNES

Le Groupe de Sociétés.

La crise du modèle légal classique de la Société Anonyme

\section{LAW No. 92/25}

Christian JOERGES

Geschichte als Nicht-Geschichte:

Unterschiede und

Ungleichzeitigkeiten zwischen

Friedrich Kessler und der

deutschen Rechtswissenschaft ***

History as Non-History:

Divergences and Time Lag between Friedrich Kessler and

German Jurisprudence

\section{LAW No. 92/26}

Michael KING/Catherine KRATZ

La Notion d'Intérêt de l'Enfant en

Droit: Vecteur de Coopération ou d'Interférence?

\section{LAW $92 / 27$}

Massimo LA TORRE

A National-Socialist Jurist on

Crime and Punishment - Karl

Larenz and the So-Called

'Deutsche Rechtserneuerung'

\section{LAW No $92 / 28$}

Diarmuid ROSSA PHELAN

The Application of United States

and European Community

Domestic Trade Laws to the Imports of Nonmarket Economy GATT Contracting Parties - A Time for Change

LAW No. $92 / 29$

Susanne KALSS

Das Höchststimmrecht als Instrument zur Wahrung des Aktionärseinflusses

LAW No. 92/30

Massimo LA TORRE

Diritto, potere, dominio

Argomenti per una teoria non prescrittivistica del diritto

LAW No. 92/31

Renaud DEHOUSSE/Christian

JOERGES/Giandomenico

MAJONE/Francis SNYDER

In collaboration with Michelle EVERSON

Europe After 1992

New Regulatory Strategies

LAW No. $92 / 32$

Renaud DEHOUSSE

Does Subsidiarity Really Matter?

LAW No. $92 / 33$

Diarmuid ROSSA PHELAN

"It's God we Ought to Crucify" 
米深深

LAW No. 93/1

Massimo LA TORRE

Reglas, instituciones,

transformaciones.

Consideraciones sobre el

paradigma "Evolución del

derecho"

LAW No. $93 / 2$

Francis SNYDER

European Community Law and

International Economic Relations:

The Saga of Thai Manioc

LAW No $93 / 3$

Aidan O'NEILL

The Government of Judges

The Impact of the European

Court of Justice on the

Constitutional Order of the

United Kingdom

LAW No. 93/4

Francis SNYDER

Law and Anthropology:

A Review

LAW No. 93/5

Francis SNYDER

Soft Law and Institutional Practice

in the European Community 